\title{
Effect of Firm Characteristics on Financial Inclusions: Evidence from Women Owned Enterprises in Kenya
}

\author{
Judith Ndinda Nguli, PhD student \\ Robert Mukoswa Odunga
}

Department of Finance and Accounting, Moi University, Eldoret, Kenya

Doi:10.19044/esj.2019.v15n10p237 URL:http://dx.doi.org/10.19044/esj.2019.v15n10p237

\begin{abstract}
The aim of the paper was to establish firm characteristics on financial inclusions; evidence from women owned enterprises in Kenya. This study employed positivism approach while adopting an explanatory survey research. The target population of study comprised 8000 women owned SMEs in the North Rift Region Economic Bloc Counties. Cluster sampling was employed to group SMEs in seven Counties, while simple random was used to select a sample size of 723 . Using multiple regression model the findings revealed a negative and significant effect of firm age on financial inclusion and firm size has a positive and significant effect on financial inclusion. These results are useful in informing policies around educating women SMEs. Government of Kenya has invested enormous resources into SMEs growth. Therefore, these results will be used to package the literacy education geared on factors that contribute highest to financial inclusion. From the findings of the study, older SMEs are encouraged to keep up to date of the trends in business
\end{abstract}

Keywords: SMEs, Firm Age, Firm Size, Financial Inclusion

\subsection{Introduction}

Financial inclusion is fast becoming an important strategy in economic policy planning and development across the globe because of the significant implications that a consistent supply of funds has on the continuity and success of businesses (Demirguc-Kunt and Klapper 2012). By pursuing it, countries aim to increase the penetration of formal financial services, therefore, empower more small holder business enterprises to produce more (Beck, Demirguc-Kunt, and Maksimovic, 2005.) Because of their close proximity to markets, higher production in these businesses has a more immediate effect on currency circulation and commerce which in turn increases the revenues the government earns through taxes and fees (Hannig and Jansen 2010). For 
example, the ability to send money from one mobile subscriber to another through Kenya's MPesa platform has created opportunities for the establishment of e-commerce trading relationships where consumers and traders exchange money for goods without meeting physically. It is an especially effective strategy in developing parts of the world that have mobile alternatives to traditional banking systems that allow people to save and borrow from the comfort of their mobile devices. Such systems have not only promoted the saving culture among people who previously did not have access to financial services, but the ease with which their operations operate have also enhanced their purchasing capabilities. As a result of the increased availability and ease of access to funds management systems, there has been a flurry of innovations on and around these systems that have created new sectors and opened up new markets, therefore, encouraging higher overall economic performance by allowing SME firms to scale up their operations ang grow their firm size (Beck et al., 2008; GPFI, 2011).

SME sector performance is sine qua non to the performance of the nation. SMEs play an important role in the fight against unemployment and in providing practical and sustainable solutions to some of our societies' biggest problems and challenges. Their importance is the result of the entrepreneurial models they employ that allow them to identify the most immediate problems plaguing their communities and then devising and delivering the most effective solutions. It also allows them to grow their operations in line with the evolution of the problems they are addressing and the demands and needs of their consumers thus making them centers of innovations and further opening up newer markets. These features give SMEs unlimited growth potentials and makes their capacity to take in more talent almost exponential with the right support, according to the findings of a study by Eniola and Ektebang (2014). However, despite financing being the most important because money is the lifeline that feeds all other processes especially when a business wants to expand (Terungwa, 2012), many small holder business owners cannot access funds from external sources (Abdel, Rowena \& Robyn, 2010). There is a lot of documented evidence that small businesses as opposed to larger firms face specific constraints in raising external finance as observed by (Berger, 2008). SMEs do not have access to public capital markets and hence depend on banks for funding due to limited financial inclusion. When there is a difference between the demand for funds by SMEs and the supply of funds, a financing gap is said to occur. Financial inclusion plays a significant role performance of small and medium, particularly those that are faced by challenges of raising capital. (Tsoukas, 2011). This role is central to contemporary debates surrounding strategies for poverty reduction and economic development. 
Financial inclusion is a key driver in the creation (Popov and Roosenboom, 2013; Kim et al. 2016), survival and growth process of firms, and especially for smalls (Beck and Demirguc-Kunt, 2006) and innovative firms (Lee et al., 2015). Small firms have more constraints and difficulties to access to finance, because they tend to have riskier projects and business models (Lee et al., 2015). Like access to finance is important for firms' activities, it can consequently foster economic growth (Kim et al., 2016) and influence positively innovation (Wang, 2014). Furthermore, it was demonstrated that innovation has a positive impact on economic growth (see e.g. Hasan and Tucci, 2010; Galindo and Méndez, 2014).

As such, financial inclusions are one of the largest challenges SMEs face today. Tarique Afzal (2015) sheds light on why this area is restricted for SMEs. Banks are more focused on urban-based lending, banks are at times reluctant to delegate to rural branch levels, Lack of interest among skilled bankers to relocate to rural areas, uncertainties of the small industries due to lack of skills and knowledge of the borrower, economic fluctuations, financing cost, double digit interest rates in SME. The above are just a few deterrents SMEs are facing in financial areas. However, other areas such as size of firm, capability of the firm are areas needing support. SMEs are counting on the commitment of the banking industries to continue their support of growth and development of SMEs. Promoting SME financial inclusion requires a holistic approach. To achieve meaningful, safe and sustainable SME access to finance.

Nevertheless, although there has been growing recognition of the importance of SMEs for job creation and economic development, SMEs themselves report lack of access to finance to be one of the greatest barriers to their growth. Half of SMEs in emerging markets are credit constrained. Seventy percent of micro, small, and medium enterprises (MSMEs) have no access to external finance, and another 15 percent are under-financed (IFC, 2013). All this adds up to an estimated credit gap of US $\$ 2$ trillion. Policy reforms vary from country to country such as loan guarantees, government funding, regulations requiring SME structure for SME finance. Studies showed that increased financial inclusion has affected SMEs positively. Thus, the study hypothesized that;

Ho1: Firm Characteristics (firm size and firm age) have no significant effect on financial Inclusions

\subsection{Empirical review}

Financial inclusion is related to firm specific variables (Kira \& He, 2012). Previous studies have shown these factors have influence on financial inclusion and therefore were controlled for this study. For instance, Kumar \& Rao (2015) found out that a firms age matters in making financial decisions as more young and new firms are inclined towards bootstrap financing which 
mostly include the owners financing. Further, information asymmetry takes a greater importance for young SMEs since they have not been established enough to earn reputation, credibility, and tangible business assets to obtain credit at favorable terms (Serrasqueiro \& Nunes, 2012). Moreover, Dwyer \& Gilmore (2017) in their research found out that market orientation varies with the size of the firm which is therefore prudent to control for it. Le (2012) found that firm dummies are statistically significant to the probability of being financial included. Burkart and Ellingsen (2004) showed that a larger firm size tends to have more financial inclusion and can provide greater access to finance. This is also supported by Beck and Demirguc-Kunt (2006), Kira and He (2012), and Mulaga (2013). They all found that larger firms have a higher access to financing than smaller ones. Odeyemi (2010) and Fatoki and Asah (2011) found that firm size is positively associated with access to finance. The positive relationship between firm size and the access to bank loans is also demonstrated for Vietnam (Le, 2012). Another determinant is the maturity of a firm measured in years. A higher age of a firm brings about a positive effect on the probability of getting a bank loan (Fatoki \& Asah, 2011; Kira \& He, 2012; Le, 2012).

\subsection{Firm Size and Financial Inclusion}

The firm's size has a crucial weight on financial inclusion of the firm (Burkart \& Ellingsen, 2004). Large firms tend to be well diversified in their operations which influence their stability; thereby size can be substituted for insolvency (Honhyan, 2009). Cassar (2004) stipulated that small firms find more expensive in solving problems associated information asymmetry with lenders. Fatoki and Asah (2011) find out that firm size impacts SMEs financial inclusion and access to finance from commercial banks whereby small enterprises are less favored to large firms. Consequently, it's hypothetical existence of a positive association between the firm size and SMEs financial inclusion.

A plethora of studies such as Francisco and Kumar (2005), Kunchev et al. (2012), Bigsten et al. (2003), Beck et al. (2005), Vergas and Mauricio (2012) and Nikaido et al. (2015) have shown that size is a significant predictor of financial inclusion. However, the effect of size on financial inclusion is associated with perceived higher risks and cost by banks which small businesses pose in lending, in comparison to large firms. In supplying credit to borrowers, the goal or aim of the bank is to minimise risk while maximising returns (Chapman \& Martin, 2007). The first risk banks that face is that of lending to a borrower who is a high risk in terms of low payback probability. One way of minimising this risk is if the lending bank has information that enables it to ascertain the risk to a reasonable extent (Cressy, 2000 \& Kasekende, 2001). In this regard, smaller businesses are more informationally 
opaque than large firms. Little, if any, public information is known about their performances because they scarcely have public equity or debt securities (Board of Governors of the Federal Reserve System, 2012). More so, Binks and Ennew (1996) pointed out that small businesses have poor or no audited financial statements and performance analysis was done by external organizations. Hence, the argument that small firms are likely to be screened out of the credit market because of information opacity is acute in small businesses. In addition to the problem of information opacity associated with SMEs, another problem is that small firms are more likely than large firms to be associated with real risk (Lung and Wright, 1999, and Gertler and Gilchrist, 1991). It is has been argued that during times of economic downturn, small businesses are less able to survive due to fewer opportunities for diversification (Klapper et al.,2002, Hughes and Storey, 1994). Contrasting these with large firms that are more diversified, established and older, hence their ability to cope with economic downturn is greater (Brewer et al., 1996). Saito and Villanueva (1981) argued that all of the above-mentioned differences translate to a higher transaction cost of lending to small businesses as compared to large firms. According to Saito and Villanueva (1981), the real cost of lending to small businesses as compared to large firms is approximately twice as great. Thus, the study argues that firm size has effect on financial inclusion.

\subsection{Firm age and Financial Inclusion}

Firms at the early stage of operation used to experience difficulties in and financial inclusion because of informational disparities. For example, According to Diamond (2013), lenders learns certain characteristics of borrowers over the years, and decide whether to grant credit according to the obtained information. Thus, trade credit may play a relevant role for younger firms that have not yet acquired a sufficient level of reputation, credit worthiness, and size, and therefore present low debt capacity.

The longevity of the firm stays in operation, the more persistence to unpleasant economic circumstances (Chandler, 2009). The study conducted by Klapper (2010) discovered that, the firms with less than 5 years (younger firms) in operation are less likely to be financially included. Ngoc, Le and Nguyen (2009) supported the argument that younger firms face hardship and more costs in accessing external financing from lenders because information asymmetry. Consequently, it is hypothetical existence of a positive relationship between firm's age and and Financial Inclusion.

The main thrust with the age of the firm and bank credit availability is that the firm's age is expected to have a dampening effect on the perceived higher risk associated with lending to SMEs. Study by Men and Dong (2014) carried out on emerging economies found evidence to suggest that younger 
and smaller firms are more credit constrained than older firms. A study done by Federal Reserve Board of Governors (2012) in US notes that older firms have more success than younger firms of the same size in getting loans from commercial banks. These differences are attributed to the fact that older firms have more records or information available for credit decisions, than younger firms. Hence, they are more likely to be granted a loan rather than the younger, informationally opaque firms. Berger and Udell (1995) found that the older the firm, the lower the loan rate charged by the banking institution. Their result showed that a small firm, with all criteria equal except it was 10 years older, paid a 33 basis point less on loan rate. In addition to the above finding, Korting and Harhoff (1998) further found in their study of German SMEs that a firm's age had a positive correlation with the cost of the loan as well as the collateral requirement. However, a study by Yang et al. (2012) on 113 developing countries suggested that once the size of the firm was controlled, the age of the firm had no significant effect on credit availability.

\subsection{Methodology}

The study employed positivism approach and adopted an explanatory survey research. The design chosen is appropriate because it applies closely to the research objectives of this study and is practical in testing the study hypotheses. The target population of study comprised 8000 women owned SMEs in the North Rift Region Economic Bloc Counties. The choice of women owned enterprises was bound by the fact that the respondents hailed from developing economies and culturally women were not allowed to own assets and bank accounts. Consequently, their levels of financial exclusion are higher. Moreover, financial access by SMEs have myriad of hurdles which are due to inability of them to be managed professionally and lack of requisite financial management skills thus they rarely have reliable books of accounts for ease of loan evaluation. Cluster sampling was employed to group SMEs in seven Counties, while simple random was used to select a sample size of 723 . The study utilized primary data derived from interviews using structured questionnaires

\subsection{Measurement of Variables}

Financial inclusion scale was adopted form the Word Bank (2012) scale. A ten item instrument was developed on a seven-point likert scale of 17 ( 1 = strongly disagree to $7=$ strongly agree $)$.

Firm age was measured from the information obtained from the question "how long has the business been operating?" The information was coded in values such that 1 represented "Below 1 year", 2 represented "2-3 years", 3 represented "3-5 years", 4 represented "5-10 years" while 6 represented "Above 10 years". 
Firm size was measured from the information obtained from the question "how many employees do you have?" The information was coded in values such that 1 represented "0-5 employees ", 2 represented "6-10 employees", 3 represented "11-20 employees" and 4 represented "Above 20 to 50 employees".

\subsection{Data Process and Analysis}

Data was analyzed using descriptive statistics such as frequency, percentage, mean and standard deviations for firm age, entrepreneur age, firm size and financial inclusion. Inferential analysis which included Pearson correlation and hierarchical regression were used to test all hypotheses required for this research, with a significance alpha value $=.05$. Multiple regression model used in this study is given as;

$y=$ Financial Inclusion

$$
\mathrm{FI}=\beta_{0}+\beta_{1} \mathrm{fs}+\beta_{2} \mathrm{fa}+\rho_{\mathrm{it}} \cdots
$$

$\alpha=$ constant.

$\beta_{1} \ldots \beta_{2}=$ the slope which represents the degree in which financial inclusion as the independent variable change by one unit variables.

$\mathrm{fs}=$ firm size

$\mathrm{fa}=$ firm age

\subsection{Findings}

The section begins with the firm characteristics of the respondents and the SMEs, results on the objectives, and then, correlation and regression analysis.

\subsection{Firm characteristics}

Firm characteristics provide the researcher with critical information concerning the unit under investigation. It identifies and describes the history and nature of a well-defined research problem with reference to existing literature. Such information may contribute to understanding the direction of the relationship between the main factors under investigation. Thus, the study sought to establish the firm characteristics included firm age and the number of employees (firm size). The findings were presented in Tables 1 
Table 1: Small and Medium Enterprises Characteristics

\begin{tabular}{llcc}
\hline & & Frequency & Percent \\
\hline Firm age & Below 1yr & 108 & 17 \\
& $1-2$ yrs & 128 & 20.2 \\
& $2-3 y r s$ & 118 & 18.6 \\
& $3-5 y r s$ & 113 & 17.8 \\
& $5-10 y r s$ & 97 & 15.3 \\
No. of employees & Above 10yrs & 70 & 11 \\
& Total & 634 & 100 \\
& $0-5$ & 515 & 81.2 \\
& $6-10$ & 80 & 12.6 \\
& $11-20$ & 22 & 3.5 \\
& Above 20 & 17 & 2.7 \\
& Total & 634 & 100 \\
\hline
\end{tabular}

The findings in Table 1 show that $20.2 \%$ of the sampled SMES's had been in operation for 1 to 2 years, $18.6 \%$ had been operating for 2 to 3 years while $17.8 \%$ had 3 to 5 years operation. Only $17 \%$ has been in operation for less than a year. Finally, it was observed that majority of SMEs $81.2 \%$ had few employees ranging from 0 to 5 while $12.6 \%$ had 6-10 employees. Only $2.7 \%$ had 11-20 employees and $2.7 \%$ had above 20 employees implying that their small sized nature.

\subsection{Descriptive and Correlation Analysis}

Correlation analysis is usually carried out in order to establish the degree to which two variables converge or diverge together depending on the case so as to determine the significance of the relationship. Usually, the Pearson's Product Moment Correlation Coefficient is used to make inference about the existing relationship between two variables. As a result, a positive value of the correlation coefficient shows that the two variables move together in the same trend, and when there is a negative value, it shows that the variables move in opposite direction. Essentially, correlation analysis depicts to a given degree, the aspect of how one factor influences another. However, correlations do not imply or infer a cause-effect relationship Correlation coefficient value range of 0.10 to 0.299 is considered weak, 0.30 to 0.49 is considered medium and 0.50 to 1.0 is considered strong. However, it shouldn't go beyond 0.8 to avoid multicollinearity. The findings revealed that firm size $\left(\mathrm{r}=0.125^{*}, \mathrm{p}<0.05\right)$ have a positive and significant correlation with financial inclusion while firm age $\left(\mathrm{r}=-0.098^{* *}, \mathrm{p}<0.01\right)$ had a negative significant correlation with financial inclusion. 
Table 2 Descriptive and Correlation Analysis

\begin{tabular}{|c|c|c|c|c|c|}
\hline & Mean & $\begin{array}{c}\text { Std. } \\
\text { Deviation }\end{array}$ & $\begin{array}{l}\text { Financial } \\
\text { Inclusion }\end{array}$ & firm size & firm age \\
\hline Financial Inclusion & 4.85 & 0.96 & 1 & & \\
\hline firm size & 1.28 & 0.66 & $0.125^{*}$ & 1 & \\
\hline firm age & 3.27 & 1.61 & $-.098 *$ & 0.03 & 1 \\
\hline
\end{tabular}

\section{Regression Analysis (Hypothesis testing)}

The study hypothesis was tested using multiple regression model at 0.05 level of significance. The results in Table 3 indicate that firm size has a positive and significant effect on financial inclusion $(\beta=.097, \mathrm{p} .05)$. Consistent with the results, Kostov et al., (2015) identified firm size as a key determinant of access and use of financial services. Small firms generate small amounts of income, and more often than not, they are less networked in comparison with older firms (Musamali \& Tarus, 2013). Traditional financial services have found it unfavorable and less profitable to engage their financial services to small firms (Erdogan, 2018). However, mobile financial services have removed the physical bureaucratic and 102 financial barriers that discriminates firms by their physical profile. Therefore, financial inclusion has expanded to the previously excluded SMEs regardless of their profile (Demirgüç-Kunt \& Klapper, 2012).

Furthermore, the findings revealed a negative and significant effect of firm age on financial inclusion $(\beta=-0.113, p>.05)$. The results are in line with previous findings which found firm age as an important determinant in the access and use of formal financial services (Beck \& Demirguc-kunt, 2006; Musamali \& Tarus, 2013). They argued that younger firms do not usually have sufficient level of reputation or tangible assets to act as collaterals in accessing credit facilities. Therefore, they are more likely to depend on personal wealth and short-term debts from family and friends (Serrasqueiro \& Nunes, 2012). Older firms on the other hand, have networks generated over time with possible good credit history eliminating the information asymmetry problem (Musamali \& Tarus, 2013). With the increasing use of digital financial services, firm age may not be as important as it were in the traditional financial system. Digital financial inclusion allows firms to benefit from saving and loan facilities without the need for collaterals. Creditworthiness is determined by established records of savings or transactions in the mobile money account and therefore firm is not a consideration to access credit. 
Table 3: Hypothesis testing

\begin{tabular}{|c|c|c|c|c|c|c|c|}
\hline & \multicolumn{2}{|c|}{$\begin{array}{c}\text { Unstandardized } \\
\text { Coefficients } \\
\text { Std. }\end{array}$} & \multicolumn{2}{|l|}{$\begin{array}{l}\text { Standardized } \\
\text { Coefficients }\end{array}$} & \multirow[b]{2}{*}{ Sig. } & \multicolumn{2}{|c|}{$\begin{array}{c}\text { Collinearity } \\
\text { Statistics }\end{array}$} \\
\hline & B & Error & Beta & t & & Tolerance & VIF \\
\hline (Constant) & 4.884 & 0.113 & & 43.139 & 0 & & \\
\hline Firm size & 0.139 & 0.057 & 0.097 & 2.454 & 0.014 & 0.999 & 1.001 \\
\hline Firm age & -0.067 & 0.023 & -0.113 & -2.878 & 0.004 & 0.999 & 1.001 \\
\hline \multicolumn{8}{|c|}{ Model Summary Statistics } \\
\hline$R$ Square & & 0.223 & & & & & \\
\hline Adjusted $R S q$ & & 0.22 & & & & & \\
\hline$F$ & & $7.406 * *$ & & & & & \\
\hline
\end{tabular}

a Dependent Variable: Average of Traditional and Mobile Financial Inclusion ** Significant at $p<0.01$

\section{Conclusion and Recommendations}

The study has contributed to our knowledge on the series of factors associated with the firms' characteristics impacts on financial inclusion in Kenya. The results demonstrate that there is interdependence and significant relationship between the firms' characteristics (size and age) and financial inclusion by SMEs

First, consistent with the extant literature, the size of the business affect financial inclusion of women owned enterprises. The probable reason for this is that larger firms are likely to have collaterals that act as a security in securing finances. Another reason is that large size in itself provides information to lenders that the firm is able to meet the needs of other constituencies and thus is able to grow in size. This could be because the women owned enterprises provide sufficient information to lenders that they are capable of meeting their financial obligations. As such, to enhance the financial inclusion of women owned enterprises, there is need for them to have collaterals that act as a security in securing finances. Also, it is important for the enterprises to provide information to lenders that they are capable of repaying loans.

Second, Firm age has been found to have a negative influence on financial inclusion of women owned enterprises. More specifically, firms that are older were found to have more access to finance. These results were not unexpected because older firms have the network capital generated overtime and also financial history that can be used to assess finance. In contrast, younger firms may lack the necessary connections on the providers of finance and also the historical performance of the firm may be lacking. The size of the firms has been an impediment to their access to finance. The results were not unexpected since the lion's share of the enterprises have been in operation for a period ranging from 1 year to 5 years. The probable reason is that the enterprises in question lack the necessary network capital as well as credit history that can be relied on to assess the enterprises credit worthiness. It is 
therefore recommended for women owned enterprises to benchmark with older firms to raise their awareness on the necessary connections on the providers of finance and also the historical performance of creditworthiness they should emulate.

\section{References:}

1. Abdel, K.H., Rowena, B. \& Robyn, D. (2010). Understanding financial information used to assess small firm performance, Qualitative Research in Accounting \& Management, 7 (2), pp. 163-179.

2. Beck, T. \& Demirguc-Kunt, A. (2006). Small and Medium Size Enterprise: Access to Finance as a Growth Constraint, Journal of Banking \& Finance, 30 (1), pp. 2931-2943

3. Beck, T., Demirgüç-Kunt, A. S. L. I., and Maksimovic, V. (2005). "Financial and Legal Constraints to Growth: Does Firm Size Matter? " The Journal of Finance, 60(1), 137-177

4. Beck, T., Demirguc-Kunt, A., \& Levine, R. (2008). SMEs, Growth, and Poverty Cross-Country Evidence. Journal of Economic Growth, 10, 199-229. https://doi.org/10.1007/s10887-005-3533-5

5. Beck, T., Demirgüç-Kunt, A., \& Maksimovic, V. (2005). Financial and Legal Constraints to Growth: Does Firm Size Matter? The Journal of Finance, 60(1), 137-177. https://doi.org/10.1111/j.15406261.2005.00727.

6. Berger, A. N., and Udell, G. F. (2008). "A More Complete Conceptual Framework for SME Finance". Journal of Banking and Finance, 30(11), 2945-2966.

7. Berger, A.N. \& Udell, G.F. (1995). A more complete conceptual framework for SME finance, Journal of Banking \& Finance, 30 (11), pp. 2945-2966

8. Bigsten, A., Collier, P., Dercon, S., Fafchamps, M., Gauthier, B., Gunning, J. W., and Zeufack, A. (2003). "Credit Constraints in Manufacturing Enterprises in Africa". Journal of African Economies, 12(1), 104-125.

9. Binks, M. R., and Ennew, C. T. (1996). "Growing Firms and the Credit Constraint”. Small Business Economics, 8(1), 17-25

10. Brewer, E., Genay, H., Jackson, W. E., and Worthington, P. R. (1996). "How Are Small Firms Financed? Evidence from Small Business Investment Companies". Economic Perspectives-Federal Reserve Bank of Chicago, 20, 2-18.

11. Burkart, M., \& Ellingsen, T. (2004). In-Kind Finance: A Theory of Trade Credit. The American Economic Review, 94(3), 569-590. https://doi.org/10.1257/0002828041464579 
12. Cassar, G. (2004). "The Financing of Business Start-Ups". Journal of Business Venturing, 19(2), 261-283

13. Chandler, V. (2009). The economic impact of the Canada small business financing program. Small Business Economics, 39(1), 253264. https://doi.org/10.1007/s11187-010-9302-7

14. Chapman, J. T., and Martin, A. (2007). "Rediscounting Under Aggregate Risk with Moral Hazard". FRB of New York Staff Report, (296)

15. Cressy, R. (2000). "Tax, Assistance, Compliance and the Performance of the Smaller Business". Federation of Small Businesses, London

16. Demirguc-Kunt, Asli; Klapper, Leora. 2012. Financial inclusion in Africa : an overview (English). Policy Research working paper ; no. WPS 6088. Washington, DC: World Bank. http://documents.worldbank.org/curated/en/534321468332946450/F inancial-inclusion-in-Africa-an-overview

17. Deutsche Forschungsgemeinschaft, Zentrum fur Europaische Wirtschaftsforschung, Mannheim Germany, Working Paper

18. Diamond, A. (2013). Executive Functions. Annual Review of Psychology, 64, 135-168. http://dx.doi.org/10.1146/annurev-psych113011-143750

19. Eniola, A.A. \&Ektebang, H. (2014). SME firms performance in Nigeria: Competitive and its impact. International journal of Research studies in management, 3(2), 75-86

20. Fatoki, O., \& Asah, F. (2011). The Impact of Firm and Entrepreneurial Characteristics on Access to Debt Finance by SMEs in King Williams' Town, South Africa. International Journal of Business and Management, 6(8), 170-179. https://doi.org/10.5539/ijbm.v6n8p170

21. Fatoki, O., \& Odeyemi, A. (2010). Which New Small and Medium enterprises in South Africa have access to bank Credit? International Journal of Business and Management, 5(10), 128-136. https://doi.org/10.5539/ijbm.v5n10p128

22. Francisco, M. And Kumar, A., (2005). "Enterprise Size, Financing Patterns, and Credit Constraints in Brazil: Analysis of Data from the Investment Climate Assessment Survey" (Vol. 6). World Bank Publications.

23. Galindo, M. A.; Méndez, M. T. (2014). "Entrepreneurship, economic growth, and innovation: Are feedback effects at work?", Journal of business research, vol. 67 (5), pp. $825-829$ 
24. Gertler, M., And Gilchrist, S. (1991). "Monetary Policy, Business Cycles and the Behavior of Small Manufacturing Firms" (No. W3892). National Bureau of Economic Research.

25. GPFI, Global Partnership for financial inclusion. 2011. SME Finance Policy Guide. IFC, Washington, DC.

26. Hannig, A and S Jansen (2010): "Financial inclusion and financial stability: current policy issues", ADBI Working Paper, no 259

27. Harhoff, D. and Körting, T. (1998a). 'Lending relationships in Germany: Empirical results from survey data.' Journal of Banking and Finance, vol. 22, pp. 1317-54.

28. Harhoff, D. and Körting, T. (1998b). 'How many creditors does it take to tango? discussion paper, Conference on Industrial Structure and Input markets.' Centre for Economic Policy Research,

29. Hasan, I.; Tucci, C. (2010). "The innovation-economic growth nexus: Global evidence", Research policy, vol. 39(10), pp. 1264 1276

30. Honhyan, Y. (2009). The Determinants of Capital Structure of the SMEs: An Empirical Study of Chinese listed Manufacturing Companies. Retrieved

from www.seiofbluemountain.com/search/detail.php?id=4414

31. Hughes, A., and Storey, D. J. (Eds.). (1994). "Finance and the Small Firm". Routledge

32. IFC (2013), Closing the Credit Gap for Formal and Informal Micro, Small, and Medium Enterprises, International Finance Corporation, World Bank Group, Washington D.C

33. Kasekende, L., and Opondo, H. (2003). "Financing Small and Medium-Scale Enterprises (SMEs): Uganda's Experience”. Bank of Uganda Working Paper

34. Kim, D. H.; Lin, S. C.; Chen, T.C. (2016). "Financial structure, firm size and industry growth", International Review of Economics and Finance, Vol. 41, pp. 23-39. doi:10.1016/j.iref.2015.10.002

35. Kim, D. H.; Lin, S. C.; Chen, T.C. (2016). "Financial structure, firm size and industry growth", International Review of Economics and Finance, Vol. 41, pp. 23-39. doi:10.1016/j.iref.2015.10.002

36. Kira, A. R., \& He, Z. (2012). The Impact of Firm Characteristics in Access of Financing by Small and Medium-sized Enterprises in Tanzania. International Journal of Business and Management, 7(24), 108-119. https://doi.org/10.5539/ijbm.v7n24p108

37. Klapper, L., Laeven, L., \& Rajan, R. (2010). Entry regulation as a barrier to entrepreneurship. Journal of Financial Economics, 82(3), 591-623. http://dx.doi.org/10.1016/j.jfineco.2005.09.006 
38. Klapper, L., Sarria-Allende, V., And Sulla, V. (2002). "Small-And Medium-Size Enterprise Financing in Eastern Europe" (Vol. 2933). World Bank Publications

39. Kostov P. , Arun T. Annim, S. (2015), Access to financial services: the case of the "Mzansi" account in South Africa Rev. Dev. Finance, 5 pp. 34-42

40. Kumar, S., \& Rao, P. (2015). A conceptual framework for identifying financing Preferences of SMEs. Small Enterprise Research, 22 (1), 99-112

41. Kuntchev, V., Ramalho, R., Rodríguez-Meza, J., and Yang, J. S. (2012). "What Have We Learned From the Enterprise Surveys Regarding Access To Finance By SMEs?" Enterprise Analysis Unit of the Finance and Private Sector Development, the World Bank Group

42. Le, B., \& Nguyen, V. (2009). The Impact of Networking on Bank Financing: The Case of Small and Medium-Sized Enterprises in Vietnam. Entrepreneurship Theory and Practice, 33(4), 867-887. https://doi.org/10.1111/j.1540-6520.2009.00330

43. Lee, S., Park, G., Yoon, B., \& Park, J. (2015). Open innovation in SMEs - An intermediated network model. Research Policy, 39(2), 290-300. https://doi.org/10.1016/j.respol.2009.12.009

44. Men, C. and Dong, Y., (2014). "SME Financing in Emerging Markets: Firm Characteristics, Banking Structure and Institutions". Emerging Markets Finance and Trade, 50(1), 120-149.

45. Mulaga, A. N. (2013). Analysis of External Financing Use: A Study of Small and Medium Enterprises in Malawi. International Journal of Business \& Management, 8(7), 55-64. doi: http://dx.doi.org/10.5539/ijbm.v8n7p55

46. Musamali, M.M. and D.K. Tarus, 2013. Does firm profile influence financial access among small and medium enterprises in kenya? . Asian Economic and Financial Review, 3(6): 714-723.

47. Ngoc, T. B., Le, T., \& Nguyen, T. B. (2009). The impact of networking on bank financing: The case of small and medium enterprises in Vietnam. Entrepreneurship Theory and Practice, Vol 33, issue 4, pp.867-887

48. Nikaido, Y., Pais, J., and Sarma, M. (2015). "What Hinders And What Enhances Small Enterprises' Access To Formal Credit In India?" Available At SSRN 2557900

49. O'Dwyer, Michele \& Gilmore, Audrey, 2017. "Value and alliance capability and the formation of strategic alliances in SMEs: The impact of customer orientation and resource optimisation," Journal of Business Research, Elsevier, vol. 87(C), pages 58-68. 
50. Popov, A. and Roosenboom, P. (2013). "Venture capital and new business creation", Journal of Banking \& Finance, 37(12), pp. 4695 - 4710, doi:10.1016/j.jbankfin.2013.08.010

51. Saito, K.A. and Villanueva, D.P.(1981).’Transaction costs of credit to the small-scale sector in the Philippines". Economic Development and Cultural change, Vol.

52. Serrasqueiro, Z., P.M. Nunes (2012), "Is age a determinant of SMEs' financing decisions? Empirical evidence using panel data models", Entrepreurship Theory and Practice, 36(4), 627-654.

53. Terungwa, A. (2012), "Risk Management and Insurance of Small and Medium Scale Enterprises (SMEs) in Nigeria”, International Journal of Finance and Accounting, 1(1), 8-17

54. Tsoukas, S. (2011). "Firm survival and financial development: Evidence from a panel of emerging Asian economies", Journal of Banking \& Finance, Vol. 35 (7), pp. 1736-1752. doi:10.1016/j.jbankfin.2010.12.008

55. Wang. J. (2014). "R\&D activities in start-up firms: What can we learn from founding resources?", Technology Analysis \& Strategic Management, Vol. $26 \quad$ (5), pp. 517-529. Doi: 10.1080/09537325.2013.870990

56. World Bank. (2012). Small and Medium Enterprises (SMEs) Finance. Retrieved from http://www.worldbank.org/en/topic/financialsector/brief/smesfinance.print

57. Yang, J. S.Kuntchev, V., Ramalho, R., and Rodríguez-Meza, J., (2012). "What Have We Learned From the Enterprise Surveys Regarding Access To Finance By SMEs? " Enterprise Analysis Unit of the Finance and Private Sector Development, the World Bank Group 